\title{
Components of the metabolic syndrome among a sample of overweight and obese Costa Rican schoolchildren
}

\author{
Ileana Holst-Schumacher, Hilda Nuñez-Rivas, Rafael Monge-Rojas, \\ and Mauro Barrantes-Santamaría
}

\begin{abstract}
Background. The term "pediatric metabolic syndrome" includes a cluster of cardiovascular risk factors such as insulin resistance, dyslipidemia (including increased triglycerides and decreased HDL cholesterol), hypertension, and obesity in children. No studies have been performed on this syndrome in a pediatric population in Costa Rica.
\end{abstract}

Objective. To establish the prevalence of metabolic syndrome and its components in 8- to 10-year old prepuberal overweight and obese schoolchildren.

Methods. This cross-sectional survey was conducted in 214 overweight and obese boys and girls, aged 8 to 10 years, who were selected from six urban schools from San José, Costa Rica. Anthropometric measurements and determinations of blood glucose, insulin, triglycerides, total cholesterol, HDL cholesterol, and high-sensitivity $C$-reactive protein (hs-CRP) were performed. The homeostasis model assessment of insulin resistance (HOMA$I R$ ) index and the Castelli index were calculated to assess insulin resistance and cardiovascular risk, respectively. Social and lifestyle variables were obtained through validated questionnaires.

Results. A total of 110 boys and 104 girls participated in this study; $37.9 \%$ of them were overweight and $62.1 \%$ were obese. Compared with boys, girls were more sedentary and had higher insulin levels $(16.05 \pm 10.45 \mu \mathrm{IU} /$ $m L$ vs. $12.72 \pm 7.63 \mu \mathrm{IU} / \mathrm{mL}, \mathrm{p}=.008)$, body fat $(36.5 \%$ vs. $30.9 \%, \mathrm{p}<.001)$, and HOMA-IR indexes $(3.5 \pm$ 2.4 vs. $2.8 \pm 1.7, \mathrm{p}=.014)$ but lower HDL cholesterol

Ileana Holst-Schumacher and Mauro Barrantes-Santamaría are affiliated with the University of Costa Rica, San José; Hilda Nuñez-Rivas and Rafael Monge-Rojas are affiliated with the Costa Rican Institute for Research and Education on Nutrition and Health (INCIENSA), Tres Ríos, Cartago.

Please address queries to the corresponding author: Ileana Holst-Schumacher, Faculty of Microbiology, University of Costa Rica, San Pedro de Montes de Oca, San José 2410-2050, Costa Rica; e-mail: iholst@cariari.ucr.ac.cr.
$(0.99 \pm 0.23 \mathrm{mmol} / \mathrm{L} v \mathrm{~s} .1 .08 \pm 0.27 \mathrm{mmol} / \mathrm{L}, \mathrm{p}=.009)$. Obese children had significantly higher mean serum concentrations of insulin, hs-CRP, and triglycerides and higher insulin resistance (estimated by HOMA-IR) than overweight children, but lower mean serum levels of $H D L$ cholesterol. The prevalence of metabolic syndrome in the study population was 5.6\%. Other risk factors for developing cardiovascular disease and type 2 diabetes had high prevalence rates among the children: sedentarism (40.6\%), family history of type 2 diabetes (73.3\%), high LDL cholesterol levels $(\geq 2.84 \mathrm{mmol} / \mathrm{L})(57.0 \%)$, hyperinsulinemia $(>10.5 \mu \mathrm{IU} / \mathrm{mL})(59.8 \%)$, insulin resistance (estimated by HOMA-IR $\geq 2.4)(55.1 \%)$, and total cholesterol $(>4.39 \mathrm{mmol} / \mathrm{L})(60.7 \%)$. Children with metabolic syndrome had significantly higher body mass indexes, glucose levels, and triglyceride levels and lower HDL cholesterol levels than children without metabolic syndrome. Insulin had a very strong positive correlation with HOMA-IR values $(\mathrm{r}=0.982)$, and hs-CRP had a mild positive correlation with body mass index $(\mathrm{r}=$ $0.296)$ and body fat $(\mathrm{r}=0.320)$.

Conclusions. This study reported a prevalence of $5.6 \%$ of metabolic syndrome among a sample of Costa Rican overweight and obese prepuberal children. Lifestyle interventions focusing on weight reduction and increasing physical activities should be promoted by education and health authorities in order to avoid the early development and onset of type 2 diabetes and atherosclerosis in childhood.

Key words: Cardiovascular risk, children, dyslipidemia, insulin resistance, metabolic syndrome, overweight/obesity, syndrome $\mathrm{X}$

\section{Introduction}

The "metabolic syndrome" is a term that is used to cluster a number of cardiovascular risk factors such as insulin resistance, dyslipidemia (including increased 
triglycerides and decreased high-density lipoprotein [HDL] cholesterol), hypertension, and obesity [1-4]. Originally, this condition was defined in adults, but in the last decade the term has also been applied to children and adolescents $[5,6]$. There is no standard pediatric definition of metabolic syndrome that is accepted by the scientific community at this time, since it has not been well characterized in children in terms of diagnostic criteria [7]. Therefore, there is little information on the epidemiology of metabolic syndrome in the pediatric age group [7].

However, it is well known that obesity plays a key role in metabolic syndrome, since this condition leads to insulin resistance and cardiovascular disease $[8,9]$. The World Health Organization (WHO) has described obesity as the world epidemic of the twentieth century in all age groups [10-14], and it is considered the sixth most important risk factor contributing to the overall burden of disease worldwide [15]. In the United States in the past 25 years, the frequency of obesity has increased by 3.8 times in children aged 6 to 11 years (from $4 \%$ to $15.3 \%$ ) and by 2.6 times in the population aged 12 to 19 years (from 6.0\% to 15.5\%) [13]. In Costa Rica, according to the Institute for Research and Education on Nutrition and Health (INCIENSA), overweight and obesity are highly prevalent among schoolchildren (34.5\% and $26.2 \%$ respectively)[16]. Likewise, in the past 2 or 3 years the Children's National Hospital has reported an increasing number of cases of insulin resistance in preadolescent boys and girls [17]. However, no studies have been performed yet in Costa Rica to study the metabolic syndrome in the pediatric population.

The purpose of this study was to determine the frequency of metabolic syndrome and its components among a sample of overweight and obese prepuberal boys and girls 8 to 10 years old.

\section{Materials and methods}

\section{Study population}

A total of 214 Hispanic male and female children aged 8 to 10 years attending public and private schools in the city of San José were recruited for this study in 2003. The sample size was determined with a confidence level of $95 \%$ and a sampling error of $5 \%$. Selected overweight and obese prepuberal boys and girls from six urban schools were invited to participate in this investigation after being given a motivational speech and a written circular to be taken home. The schools were selected with probability proportional to size from a list of urban schools in the study area. The inclusion criteria included nationality, age, and a body mass index (BMI) equal to or greater than the 85th percentile for age and sex according to WHO guidelines. Prepuberal state
(Tanner stage 1) generally refers to boys and girls 10 years old and under. The mean age of appearance of Tanner stage 2, as described in the literature [18] and according to the experience of the Children's National Hospital of Costa Rica, is 12 years in girls and 13.5 years in boys. A total of 420 children agreed to participate in the study, but only 214 of them fulfilled all the inclusion criteria.

\section{Ethical procedures}

Written informed consent was obtained from the parents of the participants, and oral consent was required from each child. All procedures followed were approved in accordance with the guidelines of the bioethics committees of the University of Costa Rica and the Costa Rican Institute for Research and Education on Nutrition and Health (INCIENSA).

\section{Sociodemographic and anthropometric variables}

Information about the child's age, sex, and family history of type 2 diabetes was collected by a validated instrument offered to the parents. Another questionnaire designed for the children and administered by four trained interviewers assessed the children's physical activities at school, at home, and during leisure time. Scores ranged from 0 to 48 , and those children who scored 30 or less were considered sedentary.

Weight was measured without the subjects wearing shoes or heavy outer clothing. Height was measured with the children not wearing shoes and facing away from the stadiometer. Standing height was measured to the nearest $0.1 \mathrm{~cm}$ and weight to the nearest 0.1 $\mathrm{kg}$. To assess nutritional status, BMI was calculated as the weight in kilograms divided by the square of the height in meters. Children with BMI at or above the 85th percentile for age and sex were considered overweight, and those with BMI at or above the 95th percentile for age and sex were considered obese. BMI data for US children according to age and sex were used as cutoff values for the Costa Rican children, as recommended by the WHO Expert Committee [19]. A leg-to-leg bioimpedance portable device (model TBF-401, Tanita Corporation) was used to determine percentage of body fat. The children were asked to wear light clothing, empty their bladders, remove all metallic objects (rings, necklaces, earrings, and coins), and stand barefoot on the machine. Data on sex and height were entered manually into the system via a keyboard. Body fat was estimated by using the standard built-in prediction equations for children and printed out.

\section{Biochemical variables}

Blood was drawn after a 12 - to 14 -hour fast by 
antecubital venipuncture according to Clinical and Laboratory Standards Institute (CLSI) procedures [20] and collected into plain Vacutainer tubes (BectonDickinson). Serum was obtained by centrifugation at $6,000 \mathrm{rpm}$ for 5 minutes at $25^{\circ} \mathrm{C}$, and removal from the red cell pack was performed within 30 minutes after venipuncture. The samples were stored at $-20^{\circ} \mathrm{C}$ until biochemical tests were performed. Insulin was determined by immunoassay methods in a fully automated $\mathrm{IM}_{\mathrm{X}}$ System (Abbott Laboratories, Diagnostics Division Dainabot) with an intra-assay variation of $8 \%$. High-sensitivity C-reactive protein (hs-CRP) was quantified by an enzyme immunoassay test (Diagnostic Automation, Immunodiagnostics Division). Total serum cholesterol, HDL cholesterol, triglycerides, and glucose were determined by enzymatic colorimetric reactions using an Hitachi automated analyzer, model 911 (Roche). The intra-assay coefficients of variation of the assays were $1.8 \%$ for total cholesterol, $3.7 \%$ for HDL cholesterol, $2.1 \%$ for triglycerides, and $1.7 \%$ for glucose. Low-density lipoprotein (LDL) cholesterol was calculated by the equation of Friedewald et al. [21]. The Castelli index was determined by dividing the total cholesterol level by the HDL cholesterol level and was defined as indicating a risk of cardiovascular disease when it was over 4.5 [22]. Serum levels of total cholesterol greater than $4.39 \mathrm{mmol} / \mathrm{L}$ and of LDL cholesterol greater than or equal to $2.84 \mathrm{mmol} / \mathrm{L}$ were considered as risk factors according to the National Cholesterol Education Program Guidelines [23]. A level of hs-CRP above $8.2 \mathrm{mg} / \mathrm{L}$ was considered high [22], and fasting hyperinsulinemia in prepuberal children was defined as a serum insulin level greater than $10.5 \mu \mathrm{IU} / \mathrm{mL}$ [7].

Insulin resistance was established by the homeostasis model assessment of insulin resistance (HOMAIR): [fasting insulin $(\mathrm{mIU} / \mathrm{L}) \times$ fasting glucose $(\mathrm{mmol} / \mathrm{L})] / 22.5$. Prepuberal participants were classified as having insulin resistance when HOMA-IR was equal to or greater than 2.4 [7]. Metabolic syndrome was diagnosed in accordance with the criteria proposed by Tapia-Ceballos [10]: high triglyceride levels $(\geq 1.24$ $\mathrm{mmol} / \mathrm{L})$, low HDL cholesterol $(<1.03 \mathrm{mmol} / \mathrm{L})$, and high fasting glucose $(\geq 5.55 \mathrm{mmol} / \mathrm{L})$.

\section{Data analysis}

Statistical analysis was performed with SPSS, version 10.0 for Windows. Student's $t$-test was used for the analysis of normally distributed data and the MannWhitney $U$-test for skewed data. Continuous variables are expressed as means $\pm \mathrm{SD}$ and categorical variables as frequencies. A value of $p<.05$ was considered to indicate statistical significance. Nonparametric Spearman's correlation coefficients were calculated for biochemical and anthropometric variables.

\section{Results}

The mean age of the 110 boys and 104 girls who participated in the study was $9.14 \pm 0.80$ years; $37.9 \%$ were overweight and $62.1 \%$ were obese, with no significant differences in the percentages of overweight and obesity between boys and girls. Table 1 shows the sociodemographic, anthropometric, and biochemical characteristics of the study population. Overall, boys and girls had a similar prevalence of family history of type 2 diabetes and similar mean values of glucose, hs-CRP, triglycerides, total cholesterol, LDL cholesterol, and Castelli index. More girls than boys were sedentary $(50.0 \%$ vs. $31.8 \%, p=.010)$. Girls also had higher insulin levels $(16.05 \pm 10.45 \mu \mathrm{IU} / \mathrm{mL}$ vs. 12.72 $\pm 7.63 \mu \mathrm{IU} / \mathrm{mL}, p=.008)$, more body fat $(36.5 \%$ vs. $30.9 \%, p<.001)$, and higher HOMA-IR indices (3.5 \pm 2.4 vs. $2.8 \pm 1.7, p=.014)$ than boys but lower HDL cholesterol levels $(0.99 \pm 0.23 \mathrm{mmol} / \mathrm{L}$ vs. $1.08 \pm 0.27$ $\mathrm{mmol} / \mathrm{L}, p=.009)$. Obese children had significantly higher mean serum concentrations of insulin, hs-CRP, and triglycerides than overweight children. Insulin resistance, as estimated by HOMA-IR, was also higher in obese than in overweight children. Obese children had lower mean serum levels of HDL cholesterol than overweight children (data not shown).

The prevalence of metabolic syndrome in the study population was $5.6 \%$ overall (table 2 ), $3.8 \%$ in overweight children, and $6.9 \%$ in obese children. The prevalence of high triglyceride levels $(\geq 1.24 \mathrm{mmol} / \mathrm{L})$ was $48.1 \%, 54.7 \%$ had low HDL cholesterol $(<1.03$ $\mathrm{mmol} / \mathrm{L}$ ), and $9.3 \%$ had high fasting glucose concentrations $(\geq 5.55 \mathrm{mmol} / \mathrm{L})$. More girls than boys had fasting hyperinsulinemia $(>10.5 \mu \mathrm{IU} / \mathrm{mL})(68.3 \%$ vs. $51.8 \%, p=.020$ ). Other risk factors for developing cardiovascular disease and type 2 diabetes had overall high prevalence rates among the study population: sedentarism (40.6\%), family history of type 2 diabetes (73.3\%), high LDL cholesterol levels $(\geq 2.84 \mathrm{mmol} / \mathrm{L})$ (57.0\%), hyperinsulinemia (> $10.5 \mu \mathrm{IU} / \mathrm{mL})(59.8 \%)$, insulin resistance (HOMA-IR $\geq 2.4)(55.1 \%)$, and high total cholesterol levels $(>4.39 \mathrm{mmol} / \mathrm{L})(60.7 \%)$.

In the overall population, $48.1 \%$ had one of the risk factors for the metabolic syndrome, $7.5 \%$ had two risk factors, and 5.6\% had three risk factors (table 3 ).

The sociodemographic, anthropometric, and biochemical characteristics of the children with and without metabolic syndrome are summarized in table 4 . Children with metabolic syndrome had significantly higher BMIs ( $24.45 \pm 4.86$ vs. $22.54 \pm 3.11, p=.047)$, glucose levels $(5.84 \pm 0.46 \mathrm{mmol} / \mathrm{L}$ vs. $4.89 \pm 0.43$ $\mathrm{mmol} / \mathrm{L}, p<.001)$, and triglyceride concentrations $(2.97 \pm 1.34 \mathrm{mmol} / \mathrm{L}$ vs. $1.37 \pm 0.81 \mathrm{mmol} / \mathrm{L}, p<.001)$ and lower HDL cholesterol levels $(0.81 \pm 0.12 \mathrm{mmol} / \mathrm{L}$ vs. $1.05 \pm 0.25 \mathrm{mmol} / \mathrm{L}, p=.001$ ) than children without metabolic syndrome. Among the children with insulin 
TABLE 1. Sociodemographic, anthropometric, and biochemical characteristics of the study population ${ }^{a}$

\begin{tabular}{|c|c|c|c|c|}
\hline Characteristic & $\begin{array}{c}\text { Boys } \\
(n=110)\end{array}$ & $\begin{array}{c}\text { Girls } \\
(n=104)\end{array}$ & $p$ value $^{b}$ & $\begin{array}{c}\text { Total } \\
(n=214)\end{array}$ \\
\hline Age $-y r$ & $\begin{array}{c}9.21 \pm 0.78 \\
(8.00-10.00)\end{array}$ & $\begin{array}{c}9.08 \pm 0.82 \\
(8.00-10.00)\end{array}$ & .236 & $\begin{array}{c}9.14 \pm 0.80 \\
(8.00-10.00)\end{array}$ \\
\hline \multicolumn{5}{|l|}{ Nutritional status-\% } \\
\hline Overweight & 37.3 & 38.5 & .968 & 37.9 \\
\hline Obese & 62.7 & 61.5 & .968 & 62.1 \\
\hline \multicolumn{5}{|l|}{ School-\% } \\
\hline Public & 80.0 & 77.9 & .834 & 79.0 \\
\hline Private & 20.0 & 22.1 & .834 & 21.0 \\
\hline Sedentarism-\% & 31.8 & 50.0 & .010 & 40.7 \\
\hline $\begin{array}{l}\text { Family history of type } 2 \\
\text { diabetes-\% }\end{array}$ & 75.2 & 72.1 & .719 & 73.7 \\
\hline $\mathrm{BMI}-\mathrm{kg} / \mathrm{m}^{2}$ & $22.50 \pm 3.28$ & $22.80 \pm 3.20$ & .499 & $22.65 \pm 3.24$ \\
\hline Body fat- $\%$ & $30.9 \pm 6.8$ & $36.5 \pm 6.4$ & $<.001$ & $33.6 \pm 7.2$ \\
\hline Glucose $-\mathrm{mmol} / \mathrm{L}^{c}$ & $\begin{array}{l}4.99 \pm 0.43 \\
(3.22-6.22)\end{array}$ & $\begin{array}{l}4.90 \pm 0.54 \\
(3.00-7.16)\end{array}$ & .178 & $\begin{array}{l}4.94 \pm 0.49 \\
(3.00-7.16)\end{array}$ \\
\hline Insulin $-\mu \mathrm{IU} / \mathrm{mL}$ & $\begin{array}{l}12.72 \pm 7.63 \\
(1.40-57.00)\end{array}$ & $\begin{array}{c}16.05 \pm 10.45 \\
(2.30-77.00)\end{array}$ & .008 & $\begin{array}{l}14.35 \pm 9.25 \\
(1.40-77.00)\end{array}$ \\
\hline hs-CRP-mg/L & $\begin{array}{c}3.10 \pm 2.69 \\
(0.50-10.00)\end{array}$ & $\begin{array}{c}3.06 \pm 2.31 \\
(0.30-10.10)\end{array}$ & .907 & $\begin{array}{c}3.08 \pm 2.51 \\
(0.30-10.10)\end{array}$ \\
\hline Total cholesterol- $\mathrm{mmol} / \mathrm{L}^{d}$ & $\begin{array}{l}4.72 \pm 0.88 \\
(2.72-7.12)\end{array}$ & $\begin{array}{l}4.63 \pm 0.93 \\
(2.46-8.44)\end{array}$ & .468 & $\begin{array}{l}4.68 \pm 0.91 \\
(2.46-8.44)\end{array}$ \\
\hline $\mathrm{HDL}$ cholesterol$-\mathrm{mmol} / \mathrm{L}^{d}$ & $\begin{array}{l}1.08 \pm 0.27 \\
(0.34-1.84)\end{array}$ & $\begin{array}{l}0.99 \pm 0.23 \\
(0.36-1.68)\end{array}$ & .009 & $\begin{array}{l}1.04 \pm 0.25 \\
(0.34-1.84)\end{array}$ \\
\hline $\mathrm{LDL}$ cholesterol $-\mathrm{mmol} / \mathrm{L}^{d}$ & $\begin{array}{l}2.98 \pm 0.79 \\
(0.85-4.97)\end{array}$ & $\begin{array}{l}2.96 \pm 0.82 \\
(0.98-6.99)\end{array}$ & .856 & $\begin{array}{l}2.97 \pm 0.80 \\
(0.85-6.99)\end{array}$ \\
\hline Triglycerides $-\mathrm{mmol} / \mathrm{L}^{e}$ & $\begin{array}{l}1.44 \pm 1.05 \\
(0.04-6.27)\end{array}$ & $\begin{array}{l}1.48 \pm 0.78 \\
(0.46-4.25)\end{array}$ & .753 & $\begin{array}{l}1.46 \pm 0.92 \\
(0.04-6.27)\end{array}$ \\
\hline Castelli index & $\begin{array}{c}4.7 \pm 1.5 \\
(2.4-11.0)\end{array}$ & $\begin{array}{l}4.8 \pm 1.3 \\
(2.5-9.4)\end{array}$ & .604 & $\begin{array}{c}4.7 \pm 1.4 \\
(2.4-11.0)\end{array}$ \\
\hline HOMA-IR & $\begin{array}{c}2.8 \pm 1.7 \\
(0.3-11.7)\end{array}$ & $\begin{array}{c}3.5 \pm 2.4 \\
(0.6-18.6)\end{array}$ & .014 & $\begin{array}{c}3.2 \pm 2.1 \\
(0.3-18.6)\end{array}$ \\
\hline
\end{tabular}

BMI, body mass index; HOMA-IR, homeostasis model assessment of insulin resistance; HDL, high-density lipoprotein; hs-CRP, high-sensitivity C-reactive protein; LDL, low-density lipoprotein

$a$. Plus-minus values are means $\pm \mathrm{SD}$. Numbers in parentheses are ranges.

$b$. Differences are considered significant if $p<.05$ (Mann-Whitney test)

c. To convert $\mathrm{mmol} / \mathrm{L}$ glucose to $\mathrm{mg} / \mathrm{dL}$, divide by 0.0555 .

$d$. To convert $\mathrm{mmol} / \mathrm{L}$ cholesterol to $\mathrm{mg} / \mathrm{dL}$, multiply by 38.7 .

e. To convert $\mathrm{mmol} / \mathrm{L}$ triglycerides to $\mathrm{mg} / \mathrm{dL}$, multiply by 88.6 .

resistance (HOMA-IR $\geq 2.4$ ), the prevalence of metabolic syndrome increased to $8.5 \%$ (data not shown).

Nonparametric Spearman correlations among biochemical and anthropometric values showed very strong positive correlations between insulin and HOMA-IR $(r=0.982)$ and between total cholesterol and LDL cholesterol $(r=0.909)$. Body fat correlated positively with triglycerides $(r=0.376)$. HDL cholesterol had a mild negative correlation with body fat $(\mathrm{r}=-0.400)$, triglycerides $(r=-0.542)$, and Castelli index $(r=-0.684)$. hs-CRP showed a mild positive correlation with BMI $(r=0.296)$ and body fat $(r=$ 0.320) (data not shown).

\section{Discussion}

To our knowledge, this is the first study that reports the prevalence of metabolic syndrome and its components among overweight and obese Costa Rican children. Definitions by WHO, the National Cholesterol Education Program's Adult Treatment Panel II (NCEP-ATP 
TABLE 2. Prevalence of the metabolic syndrome abnormalities according to the criteria proposed by TapiaCeballos [10] and other well-known cardiovascular risk factors ${ }^{a}$

\begin{tabular}{|c|c|c|c|c|}
\hline Risk factor & $\begin{array}{c}\text { Boys } \\
(n=110)\end{array}$ & $\begin{array}{c}\text { Girls } \\
(n=104)\end{array}$ & $p$ value $^{b}$ & $\begin{array}{c}\text { Total } \\
(n=214)\end{array}$ \\
\hline Metabolic syndrome & $4(3.6)$ & $8(7.7)$ & .314 & $12(5.6)$ \\
\hline High triglycerides $(\geq 1.24 \mathrm{mmol} / \mathrm{L})^{c}$ & $48(43.6)$ & $55(52.9)$ & .221 & $103(48.1)$ \\
\hline Low HDL cholesterol $(<1.03 \mathrm{mmol} / \mathrm{L})^{d}$ & $50(45.4)$ & $67(64.4)$ & .008 & $117(54.7)$ \\
\hline High fasting glucose $(\geq 5.55 \mathrm{mmol} / \mathrm{L})^{e}$ & $8(7.3)$ & $12(11.5)$ & .412 & $20(9.3)$ \\
\hline \multicolumn{5}{|l|}{ Other risk factors } \\
\hline Sedentarism & $35(31.8)$ & $52(50.0)$ & .010 & $87(40.6)$ \\
\hline Family history of type 2 diabetes & $82(75.2)$ & $75(72.1)$ & .809 & $157(73.3)$ \\
\hline hs-CRP > $8.2 \mathrm{mg} / \mathrm{L}$ & $9(8.2)$ & $6(5.8)$ & .675 & $15(7.0)$ \\
\hline $\mathrm{LDL}$ cholesterol $\geq 2.84 \mathrm{mmol} / \mathrm{L}^{d}$ & $63(57.3)$ & $59(56.7)$ & .961 & $122(57.0)$ \\
\hline Castelli index $>4.5$ & 49 (44.5) & $54(51.9)$ & .344 & $103(48.1)$ \\
\hline Fasting hyperinsulinemia (> $10.5 \mu \mathrm{IU} / \mathrm{mL}$ ) & $57(51.8)$ & $71(68.3)$ & .020 & $128(59.8)$ \\
\hline HOMA-IR $\geq 2.4$ & $55(50.0)$ & $63(60.6)$ & .155 & $118(55.1)$ \\
\hline Total cholesterol $>4.39 \mathrm{mmol} / \mathrm{L}^{d}$ & $70(63.6)$ & $60(57.7)$ & .457 & $130(60.7)$ \\
\hline
\end{tabular}

HDL, high-density lipoprotein; HOMA-IR, homeostasis model assessment of insulin resistance; hs-CRP, high-sensitivity C-reactive protein; LDL, low-density lipoprotein

a. Figures represent number (percent) of children.

$b$. Differences are considered significant if $p<.05$ (Student's $t$-test).

c. To convert $\mathrm{mmol} / \mathrm{L}$ triglycerides to $\mathrm{mg} / \mathrm{dL}$, multiply by 88.6 .

$d$. To convert $\mathrm{mmol} / \mathrm{L}$ cholesterol to $\mathrm{mg} / \mathrm{dL}$, multiply by 38.7 .

e. To convert $\mathrm{mmol} / \mathrm{L}$ glucose to $\mathrm{mg} / \mathrm{dL}$, divide by 0.0555 .

III), the European Group for the Study of Insulin Resistance, the American College of Endocrinology, and the International Diabetes Federation are reported in the literature for the diagnosis of metabolic syndrome in adults. Table 5 shows the various definitions proposed since 2003 for pediatric metabolic syndrome and the diagnostic criteria used in each case. Whereas Cook et al. [24] and de Ferranti et al. [25] modified the adult NCEP-ATP III criteria for adolescents, Viner et al. [26] adapted the WHO criteria for children and used hyperinsulinism and hypercholesterolemia as additional components of the metabolic syndrome. In this study, we used the most recent definition proposed by Tapia-Ceballos [10] in 2007, which includes the new cutoff values for fasting glucose recommended by the American Diabetes Association in 2005 [27].

The reported prevalence data for metabolic syndrome in children and adolescents in different countries vary markedly. Some studies worked with the general population, and others used samples of overweight and obese children. In addition, the inconsistent definition criteria used for metabolic syndrome and slightly different cutoff values for triglycerides, HDL cholesterol, blood pressure, and fasting glucose could explain the discrepancies found in the prevalence data reported worldwide $[6,28]$, making comparisons very difficult. Hamidi et al. [3] reported a frequency of metabolic syndrome of $20.8 \%$ in 505 obese Iranian children aged 7 to 12 years, and Ferreira et al. [29] reported a similar prevalence of $17.3 \%$ of metabolic syndrome among 52 obese Brazilian schoolchildren aged 7 to 10 years. Cook et al. [24] analyzed a sample of adolescents aged 12 to 19 years from the Third National Health and Nutrition Examination Survey (NHANES III) using the same components of Ferreira's study but with different cutoff points for the parameters. They found a prevalence of metabolic syndrome of $6.8 \%$ and $28.7 \%$ among overweight and obese adolescents, respectively. Meanwhile, Caceres et al. [30] found a prevalence of metabolic syndrome of $36 \%$ in a group of 61 obese Bolivian children and adolescents aged between 5 and 18 years. In our study, we found a prevalence of metabolic syndrome of

TABLE 3. Number and percentage of children with none, one, two, or three of the risk factors for the metabolic syndrome according to the criteria proposed by Tapia-Ceballos [10]

\begin{tabular}{|l|c|c|c|c|}
\hline $\begin{array}{l}\text { No. of } \\
\text { risk } \\
\text { factors }\end{array}$ & $\begin{array}{c}\text { Boys } \\
(n=110)\end{array}$ & $\begin{array}{c}\text { Girls } \\
(n=104)\end{array}$ & $p$ value $^{a}$ & $\begin{array}{c}\text { Total } \\
(n=214)\end{array}$ \\
\hline 0 & $52(47.3)$ & $31(29.8)$ & .014 & $83(38.8)$ \\
$1^{b}$ & $48(43.6)$ & $55(52.9)$ & .221 & $103(48.1)$ \\
$2^{c}$ & $6(5.5)$ & $10(9.6)$ & .379 & $16(7.5)$ \\
$3^{d}$ & $4(3.6)$ & $8(7.7)$ & .314 & $12(5.6)$ \\
\hline
\end{tabular}

a. All differences are significant at $p<.05$ (Student's $t$-test test).

$b$. Only high serum triglycerides $(\geq 1.24 \mathrm{mmol} / \mathrm{L}$ ) (to convert $\mathrm{mmol} / \mathrm{L}$ triglycerides to $\mathrm{mg} / \mathrm{dL}$, multiply by 88.6 ).

c. High serum triglycerides and low serum HDL cholesterol $(<1.03$ $\mathrm{mmol} / \mathrm{L}$ ) (to convert $\mathrm{mmol} / \mathrm{L}$ cholesterol to $\mathrm{mg} / \mathrm{dL}$, multiply by 38.7).

d. High serum triglycerides, low serum HDL cholesterol, and high fasting glucose $(\geq 5.55 \mathrm{mmol} / \mathrm{L}$ ) (to convert $\mathrm{mmol} / \mathrm{L}$ glucose to $\mathrm{mg} / \mathrm{dL}$, divide by 0.0555$)$. 
$3.8 \%$ and $6.9 \%$, respectively, among 214 overweight and obese schoolchildren from 8 to 10 years of age. Independently of the definition used to establish pediatric metabolic syndrome, it seems that its prevalence in overweight and obese children is increasing to worrisome limits in many countries [31,32].

In our study, insulin resistance (estimated by HOMAIR index) and mean serum concentrations of insulin were higher and HDL cholesterol levels were lower in girls than in boys and in obese than in overweight children. These results are consistent with other studies that have shown that obesity is associated with type 2 diabetes, dyslipidemia, and long-term vascular complications $[33,34]$. Likewise, it has been reported that girls have higher basal insulin levels than boys and that the levels in girls increase with age [35], a condition that makes girls more liable than boys to develop insulin resistance and type 2 diabetes. In addition, half of the girls in our study had a sedentary lifestyle, and the prevalence of low levels of HDL cholesterol was higher in girls than in boys ( $50.0 \%$ vs. $31.8 \%, p=.010)$; these results suggest that encouraging increased physical activity should be an important intervention among girls.

Many studies have shown that physical activity lowers serum cholesterol, serum triglycerides, serum glucose, and blood pressure and improves serum HDL cholesterol and insulin sensitivity. Physical activity also reduces body weight, modifies body composition, and improves cardiovascular fitness and skeletal and mental health [36-41]. Recent data also suggest that weight reduction can decrease serum levels of C-reactive protein [2].

Nine of the 12 children diagnosed with metabolic syndrome in our study (75\%) were obese, a result showing the important participation of obesity in this condition. Furthermore, children with metabolic syndrome had higher serum glucose and triglyceride levels and lower HDL cholesterol levels than children without this condition, findings that are consistent with other investigations $[42,43]$. Obese children should be

TABLE 4. Sociodemographic, anthropometric, and biochemical characteristics of Costa Rican schoolchildren with and without metabolic syndrome ${ }^{a}$

\begin{tabular}{|c|c|c|c|c|}
\hline Characteristic & $\begin{array}{l}\text { Metabolic } \\
\text { syndrome } \\
(n=12)\end{array}$ & $\begin{array}{c}\text { No metabolic } \\
\text { syndrome } \\
(n=202)\end{array}$ & $p$ value $^{b}$ & $\begin{array}{c}\text { Total } \\
(n=214)\end{array}$ \\
\hline Age- $-y r$ & $9.67 \pm 0.49$ & $9.11 \pm 0.81$ & .019 & $9.14 \pm 0.80$ \\
\hline No. males/no. females & $4 / 8$ & $106 / 96$ & NS & $110 / 104$ \\
\hline No. obese/no. overweight & $9 / 3$ & $124 / 78$ & NS & $133 / 81$ \\
\hline No. in private schools/no. in public schools & $1 / 11$ & $44 / 158$ & NS & $45 / 169$ \\
\hline Weight-kg & $46.06 \pm 11.06$ & $43.23 \pm 8.12$ & .252 & $43.40 \pm 8.30$ \\
\hline Height $-\mathrm{m}$ & $1.37 \pm 0.09$ & $1.39 \pm 0.23$ & .765 & $1.39 \pm 0.22$ \\
\hline $\mathrm{BMI}-\mathrm{kg} / \mathrm{m}^{2}$ & $24.45 \pm 4.86$ & $22.54 \pm 3.11$ & .047 & $22.65 \pm 3.24$ \\
\hline Body fat-\% & $36.43 \pm 7.07$ & $33.46 \pm 7.19$ & .166 & $33.6 \pm 7.2$ \\
\hline Sedentarism-no. (\%) & $5(41.7)$ & $82(40.6)$ & .820 & $87(40.7)$ \\
\hline Family history of type 2 diabetes-no. (\%) & $8(66.7)$ & $149(73.8)$ & .838 & $157(73.4)$ \\
\hline Glucose $-\mathrm{mmol} / \mathrm{L}^{c}$ & $5.84 \pm 0.46$ & $4.89 \pm 0.43$ & $<.001$ & $4.94 \pm 0.49$ \\
\hline Insulin $-\mu \mathrm{IU} / \mathrm{mL}$ & $16.18 \pm 8.11$ & $14.24 \pm 9.32$ & .482 & $14.35 \pm 9.25$ \\
\hline hs-CRP-mg/L & $2.57 \pm 1.41$ & $3.11 \pm 2.56$ & .470 & $3.08 \pm 2.51$ \\
\hline Total cholesterol- $\mathrm{mmol} / \mathrm{L}^{d}$ & $5.10 \pm 1.23$ & $4.65 \pm 0.88$ & .094 & $4.68 \pm 0.91$ \\
\hline HDL cholesterol- $\mathrm{mmol} / \mathrm{L}^{d}$ & $0.81 \pm 0.12$ & $1.05 \pm 0.25$ & .001 & $1.04 \pm 0.25$ \\
\hline $\mathrm{LDL}$ cholesterol- $\mathrm{mmol} / \mathrm{L}^{d}$ & $3.04 \pm 1.28$ & $3.14 \pm 2.49$ & .891 & $3.13 \pm 2.44$ \\
\hline Triglycerides $-\mathrm{mmol} / \mathrm{L}^{e}$ & $2.97 \pm 1.34$ & $1.37 \pm 0.81$ & $<.001$ & $1.46 \pm 0.92$ \\
\hline Castelli index & $6.35 \pm 1.47$ & $5.87 \pm 10.51$ & .875 & $5.9 \pm 10.2$ \\
\hline HOMA-IR & $4.21 \pm 2.09$ & $3.11 \pm 2.08$ & .077 & $3.20 \pm 2.10$ \\
\hline
\end{tabular}

BMI, body mass index; HDL, high-density lipoprotein; HOMA-IR, homeostasis model assessment of insulin resistance; hs-CRP, high-sensitivity C-reactive protein; LDL, low-density lipoprotein; NS, not significant

a. Plus-minus values are means \pm SD.

$b$. Differences are considered significant if $p<.05$ (Mann-Whitney test).

c. To convert $\mathrm{mmol} / \mathrm{L}$ glucose to $\mathrm{mg} / \mathrm{dL}$, divide by 0.0555 .

d. To convert $\mathrm{mmol} / \mathrm{L}$ cholesterol to $\mathrm{mg} / \mathrm{dL}$, multiply by 38.7 .

e. To convert $\mathrm{mmol} / \mathrm{L}$ triglycerides to $\mathrm{mg} / \mathrm{dL}$, multiply by 88.6 . 
considered a high-risk group for the development of insulin resistance, hyperinsulinemia, and cardiovascular disease at young ages. Physical activity should be encouraged among children and adolescents to prevent these chronic diseases $[41,44]$.

The overall high prevalence rates of other risk factors for the development of cardiovascular disease and type 2 diabetes found among the studied population, such as sedentarism (40.6\%), family history of type 2 diabetes (73.3\%), high serum LDL cholesterol levels (57\%), hyperinsulinemia (59.8\%), and high serum total cholesterol concentrations (60.7\%), are alarming, particularly if we consider that these factors are associated with cardiovascular disease in adults in the next 25 years of life [45] and that in Costa Rica coronary artery disease has been the main cause of death among the adult population since the 1970s [46].

Finally, in our study we determined the serum levels of hs-CRP as a marker of subclinical inflammation. This acute-phase protein has also been associated in the literature with insulin resistance, adiposity, atherosclerosis, and metabolic syndrome $[47,48]$. In our study, obese children had significantly higher mean serum concentrations of hs-CRP than overweight children $(3.52 \pm 2.70$ vs. $2.04 \pm 1.54, p<.001)$. In addition, this protein had a mild positive correlation with BMI $(r=0.296)$ and with percentage of body fat $(r=0.320)$, findings that are consistent with other investigations. Adipose tissue secretes interleukin-6, the main stimulant of the hepatic synthesis of CRP. Available evidence supports the hypothesis that CRP correlates with endothelial dysfunction and that physical exercise and diet can reduce the inflammatory response by reducing body fat and subsequently CRP levels [49]. hs-CRP is used today as a valuable marker of inflammation and predictor of coronary events [49].

Application of the metabolic syndrome concept in children and adolescents is controversial; in fact, multiple definitions of the metabolic syndrome have been proposed for children, adolescents, and adults [50]. However, our data clearly demonstrate that the metabolic syndrome and its components are present in

TABLE 5. Pediatric metabolic syndrome definitions found in the literature as of April 2008

\begin{tabular}{|c|c|c|c|c|}
\hline Diagnostic Criteria & Cook et al $^{a}(2003)$ & $\begin{array}{c}\text { de Ferranti et } \mathrm{al}^{b} \\
(2004)\end{array}$ & Viner et al $^{d}(2005)$ & $\begin{array}{l}\text { Tapia-Ceballos }{ }^{e} \\
\text { (2007) }\end{array}$ \\
\hline $\begin{array}{l}\text { Abnormal fasting } \\
\text { glucose homeostasis }\end{array}$ & $\begin{array}{c}\text { Glucose } \geq 6.1 \\
\mathrm{mmol} / \mathrm{L}\end{array}$ & $\begin{array}{c}\text { Glucose } 5.6-7.0 \\
\mathrm{mmol} / \mathrm{L}^{c}\end{array}$ & $\begin{array}{l}\text { Presence of diabetes mellitus } \\
\text { type } 2 \text { or impaired fasting } \\
\text { glucose }(\geq 6.1 \mathrm{mmol} / \mathrm{L}) \\
\text { or impaired glucose } \\
\text { tolerance }(\geq 7.8 \mathrm{mmol} / \mathrm{L} \\
\text { at } 2 \mathrm{~h} \text { ) or insulin resistance } \\
\text { estimated by HOMA-IR } \\
\text { Hyperinsulinaemia } \\
\text { (additional component) }\end{array}$ & $\begin{array}{l}\text { Presence of glucose } \\
\text { intolerance or } \\
\text { diabetes mellitus } \\
\text { type } 2\end{array}$ \\
\hline Obesity & $\begin{array}{l}\text { Waist perimeter } \\
\qquad \geq \mathrm{P}_{90}\end{array}$ & $\begin{array}{l}\text { BMI above the 95th } \\
\text { percentile for age } \\
\text { and sex }\end{array}$ & $\begin{array}{l}\text { BMI above the } 95 \text { th percen- } \\
\text { tile for age and sex }\end{array}$ & $\begin{array}{l}\text { Waist perimeter } \\
\qquad \geq \mathrm{P}_{90}\end{array}$ \\
\hline \multicolumn{5}{|l|}{ Dyslipidemia: } \\
\hline $\begin{array}{l}\text { High levels of } \\
\text { triglycerides }\end{array}$ & $\geq 1.24 \mathrm{mmol} / \mathrm{L}$ & $\geq 1.24 \mathrm{mmol} / \mathrm{L}$ & $\geq 1.75 \mathrm{mmol} / \mathrm{L}$ & $\geq 1.24 \mathrm{mmol} / \mathrm{L}$ \\
\hline $\begin{array}{l}\text { Low levels of HDL- } \\
\text { cholesterol }\end{array}$ & $<1.04 \mathrm{mmol} / \mathrm{L}$ & $\leq 0.98 \mathrm{mmol} / \mathrm{L}$ & $<0.90 \mathrm{mmol} / \mathrm{L}$ & $<1.04 \mathrm{mmol} / \mathrm{L}$ \\
\hline $\begin{array}{l}\text { High total } \\
\text { cholesterol }\end{array}$ & - & - & $\begin{array}{l}>95 \text { th percentile (additional } \\
\text { component) }\end{array}$ & - \\
\hline Arterial hypertension & $\geq \mathrm{P}_{90}$ & $\begin{array}{l}\text { (Diastolic or systolic) } \\
>95 \text { th percentile } \\
\text { adjusted for age, } \\
\text { height and sex }\end{array}$ & $\begin{array}{l}\text { Systolic }>95 \text { th percentile } \\
\text { adjusted for age and sex }\end{array}$ & $\geq \mathrm{P}_{90}$ \\
\hline
\end{tabular}

HOMA-IR, homeostasis model assessment for insulin resistance; HDL, high density lipoprotein; BMI, body mass index; P90, percentile

a. Modified version of the National Cholesterol Education Program's Adult Treatment Panel III (NCEP-ATP III) and must fulfill three of the criteria established in the table [10].

$b$. Modified version of the National Cholesterol Education Program's Adult Treatment Panel III (NCEP-ATP III) and must fulfill three of the criteria established in the table [25].

c. In accordance with American Diabetes Association recommendations (2005) [27].

$d$. Modified version of the World Health Organization (WHO) and must fulfill glucose intolerance or diabetes mellitus type 2 or insulin resistance estimated by HOMA-IR and two more criteria [26].

$e$. Modified version of Cook's et al definition of MS and must fulfill three of the criteria established in the table [10]. 
a large proportion of overweight and obese Costa Rican children. Alterations in glucose metabolism, lipid profile, and insulin sensitivity appear early in childhood when BMI increases, leading to an early onset of type 2 diabetes, hypertension, and cardiovascular disease [29, 51]. Grundy stated recently that persons with metabolic syndrome have twice the risk of cardiovascular disease and five times the risk of type 2 diabetes as those without the syndrome [52]. As stated by the National Cholesterol Education Program's Adult Treatment Panel III (NCEP-ATP III), obesity should be the primary target of intervention for metabolic syndrome [2]. Therefore, weight reduction, dietary modification, control of BMI, and increasing physical activity should become a public health priority in overweight and obese children, and these intervention actions should be promoted and encouraged in the family, school, and community in order to prevent the development of chronic diseases in a short time. Primary prevention programs are required to identify obesogenic environments, and children must be taught to develop healthy food habits and increase their physical activity $[41,53]$.

Several limitations of these data should be considered. First, because the study design was crosssectional, hs-CRP was measured in only one sample. Second, insulin resistance was estimated mathematically with HOMA-IR because the gold standard method of the euglycemic-hyperinsulinemic clamp is too expensive and invasive. Third, body-fat measurements were performed with bioimpedance equipment. Although this technique is used by many investigators, it is not very accurate. Fourth, the sample of boys and girls in this study is not representative of the population of 8- to 10-year-old overweight and obese urban schoolchildren, which limits the inferences that can be drawn with respect to the prevalence of metabolic syndrome and its components in this population. Finally, we did not measure waist circumference (abdominal obesity) in the study population, because at the time we

\section{References}

1. Reaven GM. The metabolic syndrome: Is this diagnosis necessary? Am J Clin Nutr 2006;83:1237-47.

2. Grundy SM, Brewer HB, Cleeman JI, Smith SC, Lenfant C. Definition of metabolic syndrome. Report of the National Heart, Lung, and Blood Institute/American Heart Association Conference on Scientific Issues Related to Definition. Circulation 2004;109:433-8.

3. Hamidi A, Fakhrzadeh H, Moayyeri A, Heshmat R, Ebrahimpour P, Larijani B. Metabolic syndrome and leptin concentrations in obese children. Indian J Pediatr 2006;73:593-6.

4. Expert Panel on Detection, Evaluation, and Treatment of High Blood Cholesterol in Adults: Executive summary of the third report of the National Cholesterol Education collected data, and even today, there is a lack of a standardized technique for measuring waist circumference in children, so that caution needs to be taken when comparing waist circumference percentile reference data between studies. Several cutoff values for waist circumference in children have been suggested, such as the age- and sex-specific 75th percentile to define moderate waist values $[54,55]$ and the 90 th percentile [55-57] or the 95th percentile $[54,58]$ to define high waist values or abdominal obesity. However, a possible limitation of these cutoff values is the lack of a gold standard research method, such as cross-sectional computed tomography to compare the waist circumference measures in children. In any case, our results do not support the need to measure waist circumference in addition to BMI to identify those at increased risk for metabolic syndrome in childhood.

In summary, this study reported a prevalence of metabolic syndrome of $5.6 \%$ in a sample of overweight and obese prepuberal Costa Rican children. Lifestyle interventions focused on reducing weight and increasing physical activity should be promoted by education and health authorities in order to avoid the early development and onset of type 2 diabetes and atherosclerosis.

\section{Acknowledgments}

The authors are grateful to Minor Soto Carranza, Geovanny Vargas Chaves, William Fonseca Rodríguez, and Roberto Chaves Vega for their help in collecting blood samples. We also thank Marcela Morera, Carolina Arroyo, Jennifer Villagra, Fabiola Mora, and Adatrini Chaves for their help in the data collection. This work was supported by grants from the Office of Postgraduate Studies and the Office of the Vice President for Research of the University of Costa Rica (Project 807-A3-305).

Program (NCEP) Expert Panel on Detection, Evaluation, and Treatment of High Blood Cholesterol in Adults (Adult Treatment Panel III). JAMA 2001;285:2486-97.

5. Weiss R, Dziura J, Burget TS, Tamborlane WV, Taksali SE, Yeckel CW, Allen K, Lopes M, Savoye M, Morrison J, Sherwin RS, Caprio S. Obesity and the metabolic syndrome in children and adolescents. N Engl J Med 2004;350:2362-74.

6. Amemiya S, Dobashi K, Urakami T, Sugihara S, Ohzeki T, Tajima N. Metabolic syndrome in youths. Pediatr Diabetes 2007;8(suppl 9):48-54.

7. López-Capapé M, Alonso M, Colino E, Mustieles C, Corbatón J, Barrio R. Frequency of the metabolic syndrome in obese Spanish pediatric population. Eur J 
Endocrinol 2006;155:313-9.

8. World Health Organization. Obesity: Preventing and managing the global epidemic. Technical Report Series 894. Geneva: WHO, 2000.

9. Abe Y, Kikuchi T, Nagasaki K, Hiura M, Tanaka Y, Ogawa Y, Uchiyama M. Lower birth weight associated with current overweight status is related with the metabolic syndrome in obese Japanese children. Hypertens Res 2007;30:627-34.

10. Tapia-Ceballos L. Síndrome metabólico en la infancia. An Pediatr (Barc) 2007;66:159-66.

11. Wyatt SB, Winters KP, Dubbert PM. Overweight and obesity: Prevalence, consequences, and causes of a growing public health problem. Am J Med Sci 2006; 331:166-74.

12. Deshmukh-Taskar P, Nicklas TA, Morales M, Yang SJ, Zakeri I, Berenson GS. Tracking of overweight status from childhood to young adulthood: The Bogalusa Heart Study. Eur J Clin Nutr 2006;60:48-57.

13. Ogden CL, Flegal KM, Carroll MD, Johnson CL. Prevalence and trends in overweight among US children and adolescents, 1999-2000. JAMA 2002;288:1728-32.

14. De Onis M, Blössner M. Prevalence and trends of overweight among preschool children in developing countries. Am J Clin Nutr 2000;72:1032-9.

15. Haslam DW, James WP. Obesity. Lancet 2005;366: 1197-209.

16. Núñez-Rivas H, Monge-Rojas R, León H, Roselló M. Prevalence of overweight and obesity among Costa Rican elementary school children. Pan Am J Public Health 2003; 13:24-32.

17. Holst-Schumacher I, Núñez-Rivas H, Monge-Rojas R, Barrantes-Santamaría M. Insulin resistance and impaired glucose tolerance in overweight and obese Costa Rican schoolchildren. Food Nutr Bull 2008;29:123-31.

18. Marshall WA, Tanner JM. Puberty. In: Falkner F, Tanner JM, eds. Human growth: A comprehensive treatise, 2nd ed. New York: Plenum Press, 1986:171-209.

19. World Health Organization. Physical status: The use and interpretation of anthropometry. WHO Technical Report Series No. 854. Geneva: WHO, 1995.

20. Clinical and Laboratory Standards Institute (CLSI). Procedures for the collection of diagnostic blood specimens by venipuncture: Approved standard, 5th ed. Philadelphia, PA, USA: CLSI, 1991.

21. Friedewald WT, Levy RI, Fredrickson DS. Estimation of the concentration of low density lipoprotein cholesterol in plasma without use of preparative ultracentrifugation. Clin Chem 1972;18:499-502.

22. Tietz NW, ed. Clinical guide to laboratory tests, 3 rd ed. Philadelphia, Pa, USA: W.B. Saunders, 1995.

23. National Cholesterol Education Program. Report of the expert panel on blood cholesterol levels in children and adolescents. Pediatrics 1992;89:528-34.

24. Cook S, Weitzman M, Auinger P, Nguyen M, Dietz WH. Prevalence of a metabolic syndrome phenotype in adolescents. Findings from the Third National Health and Nutrition Examination Survey, 1988-1994. Arch Pediatr Adolesc Med 2003;157:821-7.

25. de Ferranti SD, Gauvreau K, Ludwig DS, Neufeld EJ, Newburger JW, Rifai N. Prevalence of the metabolic syndrome in American adolescents: Findings from the Third National Health and Nutrition Examination
Survey. Circulation 2004;110:2494-7.

26. Viner RM, Segal TY, Lichtarowicz-Krynska E, Hidmarsh P. Prevalence of the insulin resistance syndrome in obesity. Arch Dis Child 2005;90:10-4.

27. Expert committee on the diagnosis and classification of diabetes mellitus. Report of the expert committee on the diagnosis and classification of diabetes mellitus. Diabetes Care 2005;28(suppl 1):37-42.

28. Chen W, Berenson GS. Metabolic syndrome: Definition and prevalence in children. J Pediatr (Rio J) 2007;83:1-2.

29. Ferreira AP, Oliveira CE, Franca NM. Metabolic syndrome and risk factors for cardiovascular disease in obese children: The relationship with insulin resistance (HOMA-IR). J Pediatr (Rio J) 2007;83:21-6.

30. Caceres M, Teran CG, Rodríguez S, Medina M. Prevalence of insulin resistance and its association with metabolic syndrome criteria among Bolivian children and adolescents with obesity. BMC Pediatr 2008;8:31.

31. Cook S, Weitzman M, Auinger P, Nguyen M, Dietz WH. Prevalence of a metabolic syndrome phenotype in adolescents. Arch Pediatr Adolesc Med 2003;157:821-7.

32. Duncan GE, Li SM, Zhou XH. Prevalence and trends of a metabolic syndrome phenotype among U.S. adolescents. 1999-2000. Diabetes Care 2004;27:2438-43.

33. Berenson GS, Srinivasan SR, Bao W, Newman WP 3rd, Tracy RE, Wattigney WA. Association between multiple cardiovascular risk factors and atherosclerosis in children and young adults. The Bogalusa Heart Study. N Engl J Med 1998;338:1650-6.

34. Steinberger J, Daniels SR. Obesity, insulin resistance, diabetes, and cardiovascular risk in children: An American Heart Association scientific statement from the Atherosclerosis, Hypertension, and Obesity in the Young Committee (Council on Cardiovascular Disease in the Young) and the Diabetes Committee (Council on Nutrition, Physical Activity, and Metabolism). Circulation 2003;107:1448-53.

35. Freedman DS, Srinivasan SR, Burke GL, Shear CL, Smoak CG, Harsha DW. Relation of body fat distribution to hyperinsulinemia in children and adolescents: The Bogalusa Heart Study. Am J Clin Nutr 1987;46:403-10.

36. Hirschler V, Delfino AM, Clemente G, Aranda C, Calcagno ML, Pettinicchio H, Jadzinsky M. Es la circunferencia de cintura un componente del síndrome metabólico en la infancia? Arch Argent Pediatr 2005;103:7-13.

37. Krekoukia M, Nassis GP, Psarra G, Skenderi K, Chrousos GP, Sidossis LS. Elevated total and central adiposity and low physical activity are associated with insulin resistance in children. Metabolism 2007;56:206-13.

38. Schrauwen P. Physical activity and diabetes: Current considerations. Appl Physiol Nutr Metab 2007;32:535-6.

39. Hu G, Lakka TA, Kileläinen TO, Tuomilehto J. Epidemiological studies of exercise in diabetes prevention. Appl Physiol Nutr Metab 2007;32:583-95.

40. Allen DB, Nemeth BA, Clark RR, Peterson SE, Eickhoff J, Carrel AL. Fitness is a stronger predictor of fasting insulin levels than fatness in overweight male middleschool children. J Pediatr 2007;150:383-7.

41. Ortega FB, Ruiz JR, Castillo MJ, Sjöström M. Physical fitness in childhood and adolescence: A powerful 
marker of health. Int J Obes 2008;32:1-11.

42. Sinaiko AR, Steinberger J, Moran A, Hong CP, Prineas RJ, Jacobs DR. Influence of insulin resistance and body mass index at age 13 on systolic blood pressure, triglycerides, and high-density lipoprotein cholesterol at age 19. Hypertension 2006;48:730-6.

43. Yeon Ryu S, Kweon S, Park H, Shin J, Rhee J. Obesity and the metabolic syndrome in Korean adolescents. J Korean Med Sci 2007;22:513-7.

44. Giannini C, Mohn A, Chiarelli F. Physical exercise and diabetes during childhood. Acta Biomed 2006;77(suppl 1):18-25.

45. Morrison JA, Friedman LA, Gray-McGuire C. Metabolic syndrome in childhood predicts adult cardiovascular disease 25 years later: The Princeton Lipid Research Clinics Follow-up Study. Pediatrics 2007;120:340-5.

46. Morice A, ed. Análisis de la situación de las enfermedades crónicas no transmisibles en Costa Rica. Memoria. Tres Ríos, Costa Rica: INCIENSA, 1998.

47. Soto-González A, Bellido-Guerrero D, Buño-Soto M, Pértega-Díaz S, Martínez-Olmos M, Vidal O. Metabolic syndrome, insulin resistance and the inflammation markers C-reactive protein and ferritin. Eur J Clin Nutr 2006;60:802-9.

48. Sinaiko A. Obesity, insulin resistance and the metabolic syndrome. J Pediatr (Rio J) 2007;83:3-5.

49. Rifai N, Ridker PM. High-sensitivity C-reactive protein: A novel and promising marker of coronary heart disease. Clin Chem 2001;47:403-11.

50. Reinehr T, de Sousa G, Toschke AM, Andler W. Comparison of metabolic syndrome prevalence using eight different definitions: A critical approach. Arch Dis Child 2007;92:1067-107.

51. Moschonis G, Grammatikaki E, Manios Y. Perinatal predictors of overweight at infancy and preschool childhood: The Genesis Study. Int J Obes 2008;32:39-47.

52. Grundy SM. Metabolic syndrome pandemic. Arterioscler Thromb Vasc Biol 2008;28:629-36.

53. Giannini C, Hohn A, Chiarelli F. Physical exercise and diabetes during childhood. Acta Biomed 2006;77(suppl 1):18-25.

54. Moreno LA, Fleta J, Mur L, Rodriquez G, Sarria A, Bueno M. Waist circumference values in Spanish children-gender-related differences. Eur J Clin Nutr 1999;53:429-33.

55. Fernández JR, Redden DT, Pietrobelli A, Allison DB. Waist circumference percentiles in nationally representative samples of African-American, European-American, and Mexican-American children and adolescents. J Pediatr 2004;145:439-44.

56. Maffeis C, Pietrobelli A, Grezzani A, Provera S, Tato L. Waist circumference and cardiovascular risk factors in prepubertal children. Obes Res 2001;9:179-87.

57. Cook S, Weitzman M, Auinger P, Nguyen M, Dietz WH. Prevalence of a metabolic syndrome phenotype in adolescents: Findings from the Third National Health and Nutrition Examination Survey, 1988-1994. Arch Pediatr Adolesc Med 2003;157:821-7.

58. Katzmarzyk PT. Waist circumference percentiles for Canadian youth 11-18y of age. Eur J Clin Nutr 2004; 58:1011-5. 